\title{
STRATEGI GURU DALAM MENINGKATKAN KONSENTRASI BELAJAR ANAK PADA PELAJARAN IPA MELALUI MIND MAPPING PADA SISWA KELAS V SDN DORIDUNGGA KECAMATAN DONGGO
}

\author{
Dewi Masita dan Nia Daniati \\ IAI Muhammadiyah Bima \\ Email: masithadewi.21@gmail.com \\ daniati218@gmail.com
}

\begin{abstract}
Abstrak
Penelitian ini dilatar belakangi pentingnya menerapkan metode yang digunakan yaitu metode Mind Mapping sebagai alat bantu untuk meningkatkan konsentrasi belajar anak pada saat proses pembelajaran yang sedang berlangsung guna mengatasi dari siswa yang berkesulitan konsentrasi belajarnya. Merujuk pada masalah yang terjadi pada siswa, sebagian siswa tidak serius dan tidak fokus apa yang dijelaskan oleh guru selama proses pembelajaran yang berlangsung, sulit diatur, menguap didalam kelas, menganggu teman - teman sebangkunya. Adapun Jenis penelitian dalam penelitian ini adalah penelitian kualitatif, penelitian ini dilakukan secara kolaborasi antara peneliti dan guru kelas, Peneliti melakukan penelitian di SDN Doridungga Kecamatan Donggo Kabupaten Bima. metode pengumpulan data yang digunakan adalah wawancara, dokumentasi dan observasi. Instrumen yang digunakan adalah pedoman wawancara yang digunakan untuk mengetahui peningkatan konsentrasi belajar siswa, dan pedoman observasi yang digunakan untuk mengamati siswa dan guru dalam pelaksanaan pembelajaran IPA dengan melalui metode Mind Mapping. Hasil penelitian menunjukkan bahwa pembelajaran melalui metode Mind Mapping dapat cocok diterapkan di SDN Doridunnga Kecamatan Donggo Kabupaten Bima guna meningkatkan konsentrasi Belajar anak pada pelajaran IPA pada siswa kelas V SDN Doridungga Kecamatan Donggo.
\end{abstract}

Kata Kunci : Strategi Guru, Pelajaran IPA, Mind Mapping

\section{PENDAHULUAN}

endidikan mempunyai peran yang sangat strategis dalam
meningkatkan kualitas sumber daya manusia, seperti yang
tercantum dalam Undang - undang Sistem Pendidikan Nasional No. 20 tahun 2003 Bab 2 Pasal 3: Pendidikan nasional bertujuan untuk berkembangnya potensi didik agar menjadi manusia yang beriman dan bertakwa kepada Tuhan Yang Maha Esa, berakhlak mulia, sehat, berilmu, cakap, kreatif, mandiri, dan menjadi warga negara yang demokratis serta bertanggung jawab (Dwi Siswono dkk, 2007). 
Pendidikan nasional perlu berjalan sesuai dengan tujuan yang ingin dicapai. Pencapaian tujuan pendidikan tersebut, dapat terbentuk melalui pendidikan dasar. Hal ini sesuai dengan Peraturan Menteri Pendidikan Nasional nomor 3 tahun 2006 tanggal 23 Mei 2006 yang menyatakan bahwa pendidikan dasar bertujuan untuk meletakkan dasar kecerdasan pengetahuan, kepribadian, akhlak mulia, serta keterampilan untuk hidup mandiri dan mengikuti pendidikan lebih lanjut. Salah satu instansi pendidikan dasar tersebut adalah Sekolah Dasar (SD).

Pembelajaran adalah usaha terencana dan tersusun dengan cara memanipulasikan sumber-sumber belajar sehingga terjadi proses belajar dalam diri siswa (SB Djamarah, 2000). Proses belajar mengajar pada hakikatnya adalah proses komunikasi, yaitu proses penyampaian pesan dari sumber pesan ke penerima pesan. Terkadang terjadi kendala dalam proses penyampaian pesan yang dilakukan oleh pendidik kepada peserta didik, hal ini dapat mengganggu tingkat pemahaman siswa terhadap suatu materi yang disampaikan oleh pendidik.

Strategis dalam konteks pendidikan dapat dimaknai sebagai perencanaan yang berisi serangkaian kegiatan yang didesain untuk mencapai tujuan pendidikan. Strategis dalam konteks pendidikan mengarah kepada hal yang lebih spesifik, yani khusus pada pembelajaran. Konsenkuensinya, strategi dalam kontek pendidikan dimaknai secara berbeda dengan strategi dalam konteks pembelajaran. Strategi adalah kegiatan pembelajaran yang dilakukan guru terhadap peserta didik untuk mencapai tujuan secara efektif dan efesien (Suryadi, 2013).

Dari beberapa faktor tersebut, salah satu faktor yang dapat mempengaruhi proses belajar adalah konsentrasi belajar. Konsentrasi belajar sangat besar pengaruhnya terhadap hasil belajar. Konsentrasi penuh pada siswa akan membuat siswa tersebut dapat menangkap materi yang sedang diajarkan.

Konsentrasi dapat membuat seseorang menguasai apa -apa yang dipelajarinya, karena dengan konsentrasi seluruh perhatian akan tertuju pada apa yang sedang menjadi perhatiannya. Dari hal tersebut, tentunya 
ketika konsentrasi belajar siswa meningkat, maka hasil belajarnya pun akan meningkat juga (Prayitno Erman Amti, 2006).

Bermutu atau tidaknya suatu kegiatan belajar atau optimalnya hasil belajar sangat tergantung pada intensitas kemampuan kita untuk melakukan konsentrasi belajar. Konsentrasi belajar itu tidak datang dengan sendirinya atau bukan dikarenakan pembawaan bakat seseorang yang dibawa sejak lahir, melainkan harus diciptakan dan direncanakan serta dijadikan kebiasaan belajar (Hendra Surya, 2003).

Daya konsentrasi belajar pada anak sekolah dasar dapat dikembangkan pada kelas atas (Sugiyanto, 2012). Meski bukan gangguan serius, akan tetapi kurang konsentrasi pada anak tidak boleh dibiarkan berlarut-larut. Tanpa penanganan apa pun, masalah ini bisa menetap sampai usia selanjutnya dan semakin sulit untuk ditangani (Sugihartono dkk, 2013).

Untuk mengetahui seberapa lama rentang waktu kemampuan konsentrasi seseorang, rumusnya adalah 3-5 menit dikalikan usia. Jadi, misalnya pada anak usia 10 tahun, kemampuan berkonsentrasi idealnya adalah 30-50 menit. Anak yang mencapai batas minimal kurang dari rentang waktu tersebut boleh dikatakan memiliki konsentrasi rendah (Rattih Zulhaqqi, 2013).

Dengan demikian, pembelajaran pada anak usia SD perlu dilaksanakan sedemikian rupa sehingga memungkinkan anak dapat meningkatkan proses belajar yang berpengaruh terhadap hasil belajar anak. Salah satu proses belajar yang perlu ditingkatkan yaitu kemampuan berkonsentrasi dalam menerima materi yang diajarkan.

Dalam pembelajaran IPA siswa harus memfokuskan diri untuk menerima materi yang sedang diajarkan. Pemfokusan diri tersebut dimaksudkan untuk mengembangkan sikap ingin tahu dan memudahkan anak bersikap logis (Asman Samatowa, 2010).

Berdasarkan teori di atas, maka metode pembelajaran yang digunakan guru harus dapat membantu siswa untuk aktif dalam belajar, menciptakan rasa nyaman, dan mengembangkan kemampuan kerja otak siswa. Oleh karena itu, diperlukan suatu metode pembelajaran guna 
mencapai tujuan pembelajaran IPA khususnya untuk mengembangkan konsentrasi belajar.

Mind Mapping ditemukan dan dikembangkan oleh seorang peneliti Inggris yang mengaplikasikan pengetahuan tentang otak dan proses berfikir dalam berbagai bidang kehidupan. Mind Mapping merupakan cara termudah menempatkan informasi ke dalam otak dan mengambil informasi keluar dari otak, cara mencatat kreatif, efektif, secara harfiah memetakan pikiran-pikiran kita dengan sangat sederhana (Tony Buzan, 2007).

Metode Mind Mapping dapat dijadikan alternatif solusi untuk meningkatkan konsentrasi belajar khususnya pada pembelajaran IPA antara lain: 1) mengaktifkan seluruh otak, 2) membereskan akal dari kekusutan mental, 3) memungkinkan kita berfokus untuk pokok bahasan, 4) membantu menunjukkan hubungan antara bagian-bagian informasi yang saling terpisah, 5) memberi gambaran yang jelas pada keseluruhan dan perincian, 6) memungkinkan kita mengelompokkan konsep, membantu kita membandingkannya, dan 7) mensyaratkan kita untuk memusatkan pada pokok bahasan yang membantu mengalihkan informasi tentangnya dari ingatan jangka pendek ke ingatan jangka panjang (Tony Buzan, 2007).

Berdasarkan hasil observasi awal dilakukan oleh peneliti, ditemukan tingkat konsentrasi belajar anak dalam pelajaran IPA masih dikatakan rendah, karena yang mempengaruhi konsentrasi belajar anak adalah dari faktor internal, faktor yang berasal dari individu, seperti tekad kurang kuat dalam belajar, sifat emosi, dan reaksi terhadap lingkungan, sedangakn faktor ekstermal, seperti suara gaduh orang sekitar yang mengajak berbicara, tempat belajar yang bising dan ramai, suhu ruangan, dan kelelahan juga menjadi bagian faktor eksternal, seperti kelelahan aktivitas fisik dan mental.

Selama proses pembelajaran menunjukan bahwa interaksi pembelajaran dalam kelas masih berlangsung satu arah. Pembelajaran masih berpusat pada guru, siswa menerima begitu saja informasi yang dib erikan oleh guru. Respon siswa terhadap pembelajaran cenderung rendah. Selama proses pembelajaran partisipasi siswa hanya mencatat 
dan mendengarkan penjelasan guru. Sedikit sekali siswa yang mengajukan pertanyaan maupun yang menjawab pertanyaan dari guru, bahkan siswa itu sendiri lebih asyik bermain ketimbang mendengarkan penjelasan dari guru, dan siswa tidak dialihkan untuk mencari informasi - informasi yang ada kaitannya dengan pembelajaran yang sedang diajarkan.

Berdasarkan uraian diatas tentang mata pelajaran IPA tersebut, maka peneliti tertarik untuk melakukan Penelitian di SDN Doridungga Kecamatan Donggo tentang "Strategi Guru dalam meningkatkan konsentrasi belajar anak pada pelajaran IPA melalui Mind Mapping pada Siswa Kelas V SDN Doridungga Kecamatan Donggo”.

\section{TINJAUAN TEORITIS}

1. Pembelajaran IPA di SD

IPA merupakan mata pelajaran wajib pada kurikulum KTSP di sekolah dasar. IPA di SD membuka kesempatan untuk memupuk rasa ingin tahu siswa secara alamiah. Cullingford dalam Usman Samatowa mengemukakan bahwa dalam pembelajaran IPA, siswa harus diberi kesempatan untuk mengembangkan sikap ingin tahu dan berbagai penjelasan logis. Hal ini tentunya penting, agar siswa tidak hanya dibekali dengan teori saja tanpa mengetahui proses bagaimana teori itu dapat terbentuk, sehingga siswa harus lebih memfokuskan diri untuk menerima materi yang sedang diajarkan. Pada dasarnya tujuan pembelajaran IPA di SD adalah:

a. Pencapaian sains dari segi produk, proses, dan keilmuwan.

b. Dari segi produk, siswa diharapkan dapat memahami konsep konsep Sains dan keterkaitannya dengan kehidupan sehari-hari. Dari proses, siswa diharapkan memiliki kemampuan untuk mengembangkan pengetahuan, gagasan, dan menerapkan konsep yang diperolehnya untuk menjelaskan dan memecahkan masalah yang ditemukan dalam kehidupan sehari - hari.

c. Dari segi sikap dan nilai siswa diharapkan mempunyai minat untuk mempelajari benda - benda di lingkungannya, bersikap ingin tahu, tekun, kritis, mawas diri, bertanggung jawab dapat 
bekerja sama dan mandiri, serta mengenal dan memupuk rasa cinta terhadap alam sekitar sehingga menyadari keagungan Tuhan Yang Maha Esa (Patta Bundu, 2006).

Guru mempunyai peranan penting sebagai pembimbing siswa dalam belajar. Beberapa aspek penting yang dapat diperhatikan guru dalam memberdayakan anak melalui pembelajaran IPA sesuai dengan implemenasi teori kogitif Piaget pada pembelajaran adalah:1) memusatkan perhatian kepada siswa untuk tetap fokus dalam belajar; 2) mengutamakan peran siswa dalam berinisiatif sendiri dan keterlibatan aktif dalam pembelajaran; 3) memaklumi akan adanya perbedaan individu dalam hal kemajuan perkembangan.

Dari pendapat tersebut, salah satu hal yang harus dilaksanakan guru adalah memusatkan pikiran siswa, agar siswa dapat fokus dalam menerima materi yang sedang diajarkan. Dengan kata lain, konsentrasi belajar siswa merupakan faktor penting yang harus diperhatikan guru guna mencapai hasil belajar yang diinginkan.

2. Strategi Guru Dalam Konsentrasi Belajar Siswa

Konsentrasi adalah pemusatan pikiran terhadap sesuatu hal yang mengesampingkan hal - hal lain yang tidak berhubungan dengannya. Sedangkan bila dikaitkan dengan belajar, maka konsenstrasi belajar dapat diartikan sebagai pemusatan pikiran terhadap seseuatu mata pelajaran dengan mengesampingkan hal hal lain yang tidak berhubungan dengan pelajaran.

Konsentrasi adalah suatu proses pemusatan pikiran kepada suatu objek tertentu. Ketika sedang berkonsentrasi seseorang harus berusaha keras agar segenap perhatian panca indra dan pikirannya hanya terfokus pada satu objek saja. Panca indra khususnya mata dan telinga tidak boleh berfokus pada hal - hal yang lain, pikiran tidak boleh memikirkan dan teringat masalah - masalah lain (Thursan Hakim, 2002).

Dari berbagai pengertian tersebut, konsentrasi belajar dalam penelitian ini dibatasi pada konsentrasi belajar siswa ketika menerima pelajaran di kelas, khususnya pada pelajaran IPA. Konsentrasi belajar yang dimaksud adalah tindakan atau pekerjaan yang siswa lakukan, 
dikerjakan secara sungguh - sungguh dengan memusatkan panca indra, yaitu: indra penciuman, indra pendengaran, dan indra pengelihatan siswa dalam waktu yang relatif lama pada mata pelajaran IPA.

3. Metode Mind Mapping

Mind Maping atau Peta Pikiran adalah alternatif pemikiran keseluruhan terhadap pemikiran linier. Metode Mind Mapping mengapai pikiran dari segala arah dan sudut (Tony Buzan, 2007). Senada dengan pemikiran tersebut, bahwa Mind Mapping adalah alat berpikir kreatif yang mencerminkan cara kerja alami otak dan cara termudah untuk menempatkan informasi ke dalam otak serta mengambil informai ke luar otak. Selain itu, Mind Mapping juga merupakan cara mencatat yang kreatif, efektif yang akan memetakan pikiran-pikiran kita (Tony Buzan, 2007).

Bentuk Mind Mapping seperti peta sebuah jalan di kota yang mempunyai banyak cabang. Seperti halnya peta jalan kita bisa membuat pandangan secara menyeluruh tentang pokok masalah dalam suatu area yang sangat luas. Dengan sebuah peta kita bisa merencanakan sebuah rute yang tercepat dan tepat dan mengetahui kemana kita akan pergi dan dimana kita berada (Taufik Bahaudin, 1999).

Mind Mapping bisa dibandingkan dengan peta kota yaitu bagian tengah Mind Map sama halnya dengan pusat kota yang mewakili gagasan terpenting; jalan - jalan protokol yang memancar keluar dari pusat kota yang merupakan pikiran utama dalam proses berpikir, jalan-jalan atau cabang - cabang sekunder merupakan pikiran sekunder.

Langkah - langkah pembuatan Mind Mapping adalah:

a. Menentukan ide utama yang dimulai dari bagian tengah kertas kosong yang sisi panjangnya diletakkan mendatar, memulai dari tengah memberi kebebasan kepada otak untuk menyebar ke segala arah dan untuk mengungkapkan dirinya dengan lebih bebas dan alami. 
b. Gunakan gambar (simbol) untuk ide utama, gambar bermakna seribu kata dan membantu kita menggunakan imajinasi. Sebuah gambar sentral akan lebih menarik, membuat kita tetap terfokus, membantu kita berkonsentrasi, dan mengaktifkan otak kita.

c. Gunakan warna, bagi otak warna sama menariknya dengan gambar. Warna membuat mind map lebih hidup, menambah energi kepada pemikiran kreatif, dan menyenangkan.

d. Hubungan cabang-cabang utama ke gambar pusat dan hubungkan cabang-cabang tingkat dua dan tiga ke tingkat satu dan dua, dan seterusnya. Otak bekerja menurut asosiasi, otak senang mengaitkan dua (atau tiga, atau empat) hal sekaligus. Bila kita menghubungkan cabang-cabang, kita akan lebih mudah mengerti dan mengingat.

e. Buatlah garis hubung yang melengkung karena garis lurus akan membosankan otak.

f. Gunakan satu kata kunci untuk setiap garis karena kata kunci tunggal memberi lebih banyak daya dan fleksibilitas kepada mind map.

g. Gunakan gambar yang sesuai pada setiap cabang untuk memperjelas kata kunci (Tony Buzan, 2007).

4. Implementasi Metode Mind Mapping dalam IPA

Mind Mapping dapat dimanfaatkan atau berguna untuk berbagai bidang, termasuk bidang pendidikan. Kegunaan metode Mind Mapping dalam bidang pendidikan diantaranya adalah untuk meningkatkan konsentrasi belajar dan hasil belajar siswa.

Pembelajaran IPA adalah suatu kumpulan teori yang sistematis, penerapannya secara umum terbatas pada gejala-gejala alam, lahir dan berkembang melalui metode ilmiah serta menuntut sikap ilmiah. Faktor penentu pada mata pelajaran IPA adalah dari segi proses, produk dan sikap ilmiah. Sedangkan, konsentrasi dalam belajar IPA itu dapat mempermudah siswa untuk mengembangkan sikap dan perilaku yang dimiliki.

Dalam pembelajaran IPA siswa harus memfokuskan diri untuk menerima materi yang sedang diajarkan untuk mengembangkan sikap ingin tahu dan berbagai penjelasan logis. Untuk mencapai 
tujuan itu, maka perlu adanya metode pembelajaran yang berfungsi untuk memusatkan pikiran (konsentrasi) siswa saat menerima materi ajar. Salah satu metode tersebut adalah metode Mind Mapping (Usman Samatowa, 2010).

\section{METODOLOGI PENELITIAN}

Dalam penelitian ini, peneliti menggunakan pendekatan Kualitatif, dimana peneliti dituntut untuk lebih banyak menggunakan logika, karena data yang diperoleh dari lapangan lebih banyak yang bersifat informasi dan keterangan - keterangan yang berbentuk uraian, bukan dalam bentuk angka atau berbentuk simbol. Metode penelitian kualitatif dilakukan pada kondisi yang alamiah (Natural Setting) dan data yang dikumpulkan umumnya bersifat kualitatif (Ahmad Fuad Effendi, 2005). Adapun tekhnik pengumpulan data dalam penelitian ini adalah observasi, dokumentasi dan wawancara (Sugiyono, 2009). Kegiatan analisis dan pengumpulan data dilakukan interaktif dan merupakan siklus yang berulang-ulang, berlanjut secara terus-menerus dan saling menyusun sampai kegiatan akhir dalam penelitian siap dikerjakan. Model interaktif oleh Miles dan Huberman yakni pengumpulan data, penyajian data, reduksi data, dan verifikasi data.

\section{HASIL TEMUAN}

Adapun strategi guru dalam meningkatkan konsentrasi belajar anak pada pelajaran IPA melalui metode Mind Mapping antara lain:

a. Guru memberikan informasi terlebih dahulu tentang materi atau tema yang akan dibahas pada pelajaran IPA yaitu tema "Air".

b. Selain itu pembiasaan ketika masuk guru memberikan salam dan membuka pelajaran dengan membaca dalil -dalil Al- Qur'an.

c. Sebelum masuk pada pembahasan, guru memberikan motivasi awal untuk membangkitkan semangat siswa.

d. Guru melaksanakan pembelajaran sesuai dengan RPP, Silabus guna mengelola pembelajaran dan mampu mengembangkan dirinya sendiri ataupun mengikuti perkembangan dunia pendidikan agar tidak 
ketinggalan zaman, serta menguasai materi sesuai bidang yang digelutinya.

e. Ketika guru dihadapkan kondisi pembelajaran yang labil guru mengambil tindakan intermezo, pembelajaran diluar kelas diluar ruangan. Selain itu guru menggunakan phunisment atau hukuman bagi siswa yang dinyatakan menganggu siswa yang lain setelah diberikan berupa teguran.

f. Guru memperhatikan perbedaan antara individual dalam setiap pembelajaran semua peserta didik yang memiliki latar belakang yang berbeda dan pengaruh serta kondisi yang sering berubah - urah, sehingga dalam proses pembelajaran dapat berjalan secara kondusif dan efektif.

g. Penggunaan media seperti papan tulis, guru sendiri, visual. Metode pembelajaran yang digunakan oleh guru diantaranya metode Mind Mapping .

h. Guru mengevaluasi kembali apa yang disampaikannya kepada siswa baik berupa latihan atau tanya jawab sampai mana siswa mampu menguasai materi yang dijelaskan oleh gurunya didepan selama proses pembelajaran.

i. Setelah berbagai kegiatan pembelajaran sebelum pembelajaran ditutup, guru memberikan tugas, sebagai guru membuka sesi tanya jawab, sebagai guru upaya mengevaluasi kembali pembelajaran, dan ditutup dengan do'a.

Disamping itu sebagai strategi guru dalam meningkatkan konsentrasi belajar guru harus memberikan semangat baru agar siswa kembali fokus misalnya, yel - yel, pergerakan anggota tubuh sambil bernyanyi, atau memberikan hadiah berupa nilai tambahan. Berdasarkan teori Mulyasa mengatakan untuk membangkit nafsu belajar siswa diantaranya:

a. Peserta didik akan belajar lebih giat apa bila topik yang dipelajari menarik dan berguna bagi dirinya.

b. Tujuan pembelajaran harus disusun dengan jelas dan informasikan kepada siswa, sehingga mereka mengetahui tujuan belajar peserta didik dapat juga dilibatkan dengan menyusun tujuan. 
c. Pemberian pujian dan hadiah lebaih baik daripada hukuman, namun sewaktu - waktu hukuman juga diperlukan.

d. Manfaatkan sifat, cita - cita, rasa ingin tahu, dan ambisi peserta didik.

e. Usahakan untuk memperhatiakn perbedaan individual peserta didik, misalnya perbedaan kemampuan, latar belakang, dan sikap terhadap sekolah atau subjek tertentu (Mulyasa, 2005).

Usaha untuk memenuhi kebutuhan siswa dengan menunjukan bahwa guru memperhatikan kondisi fisik, memberikan rasa aman, menunjukan bahwa guru memperhatikan mereka, mengatur pengalam belajar sedemikian rupa sehingga setiap siswa .

Demikian proses pembelajaran di SDN, mulai awal dari perencanaan sampai pelaksanaan, Runtutan perencanaan dengan beberapa langkah penyusunan perangkat pembelajaran, kesiapan guru baik fisik maupun penguasaan materi, pelaksanaan pembelajaran dengan pengunaan media, metode dan sumber secara maksimal, intermezo dan hukuman sebagai upaya meningkatkan konsentrasi dan motivasi belajar siswa.

Adapun prosedur yang dilaksanakan oleh guru yaitu antara lain:

a. Menyusun Program Pembelajaran

Guru merancang program pembelajaran dalam bentuk tertulis. Hasil rancangan ini berguna untuk menentukan warna dan corak pembelajaran yang akan dilaksanakan oleh guru diruangan kelas.

b. Melaksanakan Program Pembelajaran.

Pelaksanaan program pembelajaran sudah diatur sedemikian rupa. Program yang sudah dibuat sedemikian rupa oleh guru dilaksanakan melalui tatap muka diruangan kelas. Apakah guru sudah telah melaksanakan pembelajaran yang telah dibuat atau belum. Ini hanya akan diketahui oleh guru yang bersangkutan. Namun keberhasilan pelaksanaan pembelajaran tidak lepas dari sentuhan seni dan kreativitas guru.

c. Melaksnakan penilaian atau evaluasi

Penilaian yang dilakukan oleh guru setelah melaksanakan kegiatan pembelajaran merupakan suatu keharusan. Tujuannya untuk 
mengetahui sejauh mana siswa mampu menguasai dan menangkap apa yang dijelaskan oleh gurunya.

d. Melaksanakan analisis hasil penilain

Guru perlu menganalisa hasil evaluasi siswa. Hasil analisa ini akan bermanfaat untuk tindak lanjut terhadap terhadap hasil belajar siswa.

\section{SIMPULAN}

Guru adalah faktor utama yang menentukan mutu pendidikan. Guru berhadapan dengan siswa secara langsung didalam kelas selama proses pembelajaran. Guru harus berusaha mendesain selama proses pembelajaran yang sedang berlangsung untuk mengatasi siswa yang kesulitan kosentrasi baik itu melalui strategi, pendekatan, media, metode pembelajran untuk mencapai tujuan pembelajaran yang diharapkan. Untuk memahami kebutuhan siswa guru juga perlu memanajemenkan waktu dan memanajemenkan kelas.

Berdasarkan hasil penelitian yang dilakaukan oleh peneliti ada beberapa kendala yang dihadapi oleh guru di SDN Doridungga Kecamatan Donggo Kabupaten Bima yaitu; (a) Kekurangan APE yang digunakan, (b) sarana: Buku Paket, LCD dan kondisi lingkungan pembelajaran, (c) guru kewalahan menghadapi siswa yang mulai gaduh dengan teman sebangkunya.

\section{DAFTAR PUSTAKA}

Ahmad Fuad Effendi. 2005. Metodologi Pengajaran Bahasa Arab, Malang, Misykat.

Dwi Siswoyo, dkk. 2007. Ilmu Pendidikan, Yogyakarta, UNY Pers.

Hendra Surya. 2003. Kiat Mengajak Anak Belajar dan Berprestasi. Jakarta, Elex Media Komputindo.

Mulyasa. 2005. Menjadi Guru Profesional, Bandung, PT Remaja Rosda Karya.

Patta Bundu. 2006. Penilaian Keterampilan Proses dan Sikap Ilmiah dalam Pembelajaran Sains SD, Jakarta, Depdiknas.

Prayitno Erman Amti. 2006. Dasar - dasar Bimbingan dan Konseling, Jakarta, Depdikbud.

Ratih Zulhaqqi. 2013. Mengasah Konsentrasi. Diakses dari http://health.detik.com/ read/2013/09/06/124439/2351140/1528/anaktak-bisa-diam-dansulit-konsentrasi-di-kelas-apa-solusinya. 
SB, Djamarah. 2000. Strategi Belajar Mengajar, Jakarta, Rineka Cipta. Sugiyono. 2009. Metode Penelitian Pendidikan Pendekatan Kuantitatif, Kualitatif, dan R\&D, Bandung, Alfabeta.

Sugiyanto. 2012. Karakteristik Siswa SD, Jurnal Kependidikan Dosen UNY.

Sugihartono, dkk. 2013. Psikologi Pendidikan, Yogyakarta, UNY Press.

Suryadi. 2013. Strategi Pembelajaran Pendidikan Karakter, Bandung, PT Remaja Rosdakarya.

Taufik Bahaudin. 1999. Brainware Managemen, Jakarta, PT Elex Media Komputindo.

Thursan Hakim. 2002. Mengatasi Gangguan Konsentrasi, Jakarta, Rineka Cipta.

Tony Buzan. 2007. Buku Pintar Mind Mapping, Jakarta, PT Gramedia Pustaka Utama.

Usman Samatowo. 2010. Pembelajaran IPA di Sekolah Dasar, Jakarta. Bumi Aksara. 